\title{
PERCEPTIONS OF TURKISH CONSTRUCTION FIRMS ABOUT THE MARKETING CONCEPTS
}

\author{
Ercan ERDIS, Hilmi COSKUN, Mustafa DEMİRCI \\ Faculty of Engineering, Mustafa Kemal University, Iskenderun, Hatay, Turkey \\ Received 10 January 2012; accepted 24 August 2014
}

\begin{abstract}
Competitive marketing environment requires construction companies to come up with the right strategies to progress. This only becomes possible by preparing rigorous preconstruction feasibility studies. Additionally, the effectiveness of promotion activities of the company is important to acquire a market share which can be realized by having systematic marketing concept. In this study, the perception and application level of marketing concept of construction firms are investigated. The promotion strategies which enable the companies to have systematic applications of marketing concepts in order to compete with other companies in the sector are discussed. To evaluate the marketing attitudes as applied by the companies, a questionnaire was performed with forty nine Turkish construction firms. The perception and application of the marketing are discussed based on the organizational structure and key interest areas of construction companies. The overall result deduced is that the construction companies do not have a systematic approach to marketing. The companies have primarily adopted the approaches to keep their current places in the sector.
\end{abstract}

Keywords: competitive marketing, infrastructure, promotion activities, organizational structure, civil engineering.

JEL Classification: D22, L11, L74, M31.

\section{Introduction}

Traditionally, production and sales are the two most important tasks of any business. In the past, most of organizers believed that the quality of products or services was the only factor for selling them (Daft 1998). Due to developments in education, advances in technology and increases in society's wealth, customers are looking for the companies which have a mission and give better services. Nowadays, instead of producing something for the sake of production, the needs and tastes of customers are becoming more important. So, the marketing efforts in the production process have taken its due place in contemplating of the tasks. Marketers are interested in customers' demands, develop the services for the customers'

Corresponding author Ercan Erdis

E-mail: e_erdis@hotmail.com 
needs, set a price for these services, and inform the customers about the feasibility of these services (Perreault et al. 2010). Many companies, however, still do not pay enough attention to marketing and allocate budget for it (Pheng, Ming 1997). In today's strict competitive environment, uncertainties and changes in the surrounding businesses force companies to move in a strategically planned manner considering the marketing variables (Stuart, Slatter 1991; Zavadskas et al. 2004).

Marketing is essentially an administrative task. From the administrative point of view, marketing is a process for creating the demand and satisfying the needs. The fundamental marketing variables to create a demand include designing quality and advantageous products in response to customers' requests and needs, pricing appropriately, and promoting through personal sales or other advertising tools (Bentley 1987; Banaitis, Banaitiene 2005; Crespin-Mazet, Portier 2010).

The marketing strategies make up the focal point of marketing plan and policies of a company. The marketing strategy is to achieve the marketing goal which is presenting suitable product and service to selected customers in appropriate place with an appropriate price at a proper time, in a sensible and systematic way. A marketing strategy consists of selecting the target market and the marketing mix (product, price, advertising and distribution) phases. In order to determine the marketing strategy, a company must identify target market primarily and then it must analyze the components of the marketing mix. The first evaluations of marketing components show that the marketing consists of the product, price, promotion, place, people, physical evidence, and processes. Out of these components, it is usually understood that price, product, and people are the most important components of marketing. If satisfying the customers' needs is the primary aim of companies then quality, quantity and deadlines of products/services become important considerations at all the times because these affect the company's position in relation to competitors and the amount of demand in its sector (Korkmaz, Messner 2008).

The importance given to the marketing concept in construction industry has been increasing. It is increasingly seen that the construction companies establish the target (such as the basic skills) and strategies (effective coordination of advertising, strategies and so on.) to provide them the competitive advantages. Meanwhile the construction companies must carry out its activities to provide the goods and services where appropriate, at the appropriate time and great rates for great customer satisfaction as a rational and systematic way.

\section{Marketing concept in construction firms}

The marketing process in the construction sector is not without problems. The origin of these problems can be pinpointed to seeing the customer as if the customers do not have any knowledgeable and unable to comprehend the processes (Stuart, Slatter 1991). There has been little attention paid to understanding the customer needs and expectations, which are fundamentals of strategic marketing (Huff 1984; Cicmil, Nicholson 1998). Although having an appropriate marketing strategy is the pertinent thing while doing the business, many construction companies do not realize its true worth until it is too late to change. 
The managers in the construction sector need to have a realistic model to approach the customers (Smyth 2000; Jaradat et al. 2013). Such a model, however, is only created by using the system theory. According to this approach for the identification of a system, the system's main purpose, boundaries and parts (input, process, output, and feedback features) should be identified first. Besides, knowing the factors that are outside of the system and affect them also plays an important role in the success. The organization's policy, strategic planning, consumers, knowledge about the market, and market opportunities can be considered as the marketing system's inputs. The system process features are marketing research, evaluation, planning, and implementation activities. Outputs of the system are repeats of the previous orders, requests, and new orders. In a study by Polat, Donmez (2010a), an analytic-network-process (ANP) model was developed to aid construction companies in their marketing activities. By using this type of approach, the managers should be able to prioritize and better select the marketing activities.

The 'preliminary studies in construction' consists of the basic services that are submitted by construction companies and aimed to meet customer needs. These include such activities that selection of location and land, preparation of technical specifications of projects, determination of construction cost estimate, and arrangement of contracts. Factors such as, project complexity, conflicting objectives, lack of compatibility, lack of trust and commitment and lack of coherence between the budget and the objectives turn out to influence a co-development strategy. The role played by the key decision-makers (project manager) also influences the success/failure of co-development strategy. The functional interdependence within the project network, its power and knowledge structure and integration of the history of the relationships between its actors provide the framework to analyze this network (Hakansson et al. 1976).

Construction firms that work under the competitive tendering, first determine pricing strategies while they are establishing their marketing strategies. In construction projects, the pricing policies of companies are affected by the firm's capacity to prepare proposals, status of the external factors, and the extent of opportunities which may occur during the project lifetime. Some factors such as the intensity of competition and the size of the project affect the price of the job which is the most important component of the marketing mix (Yisa et al. 1996; Mochtar, Arditi 2001; Skaates et al. 2002; Cova, Salle 2005; Uslay et al. 2006; Crespin-Mazet, Ghamri 2007; Polat, Donmez 2010b). The various changes among the many factors, such as, the structure of the industry, procurement methods, construction processes, client organizations, technology, political and economic environments, related to construction companies' effect these companies' marketing strategies (Yisa et al. 1995; Tang et al. 2007; Arditi et al. 2008; Kajander et al. 2012; Costa, Tavares 2013).

Among the Turkish contractors, the level of marketing orientation is rather low and marketing functions are generally conducted with superficial knowledge about marketing (Dikmen et al. 2005; Demirci et al. 2003; Erdis et al. 2008; Polat, Donmez 2010b). There are misconceptions related with the benefits of marketing perspective and majority of the construction companies do not conduct marketing activities integrated with the rest of the value chain (Hardy, Davies 1983).

The traditional competitive advantages on which most of the construction firms rely, such as technical expertise, historic market connections are rapidly being eroded; so in order to maintain market share, companies should seek different, less traditional competitive advantages such as superior marketing capability (Pettinger 1998). 


\section{Materials and methods}

In this study, a questionnaire is organized firstly to determine the level of understanding about the marketing perceptions of construction companies in Turkish construction sector as a whole. There is the fact, however, that the construction sector consists of many subsectors and the companies can have different organizational structures. Thus, there is a need to determine the marketing concepts employed by construction firms considering their subsector activity areas, such as residential, commercial and infrastructure construction as well as their organizational structures such as simple, hierarchical, project and network. The analyses results can also provide clues to companies which need to adjust themselves in the construction sector to be more market-oriented. The questionnaire was prepared considering these abovementioned characteristics of the companies.

The survey is conducted by interviewing forty nine Turkish construction firms ranged from middle to large scale. $65 \%$ of survey results were obtained by going to construction firms and interviewing senior managers in person. The remaining $35 \%$ were acquired via the mail, fax, and e-mail. Having $82 \%$ of survey respondents as university graduates and as responsible persons of the companies from within the administrative and technical point (such as, general manager, construction engineers, accounting, marketing, etc.) can be thought to increase the accuracy of survey results. The results, however, reflect only these people's approach on this subject. In order to view and analyze the distribution and variability of the measured data, frequency tables were used. "Likert Scale Method" was used for graded questions.

\section{Evaluation of questionnaire results}

Findings of the study consist of assessment and interpretation of survey results. The results are used to determine the level of perception and application of marketing concepts in the construction companies.

\subsection{Demographics of surveyed companies}

The organizational structures of companies are stated as follows: simple organizational structure: 25 (51.0\%); functional/hierarchical structure: 11 (22.5\%); both product and function based partitioning (project type): 7 (14.3\%); and a network consisted of experts in and around headquarter: 6 (12.2\%) out of forty nine (100\%) companies. According to these, most of the companies have simple and functional/hierarchical organizational structures.

In the simple (classical) organizational structure that is usually used in small projects, activities of a project are performed by the corresponding departments based on their self departmental functions. In the functional or hierarchical structure, the managers of units can establish relations also to some other departments' personnel and command these personnel.

In the matrix type of organizational structures, the personnel who belong to different departments depending on their profession perform project activities under the management and coordination of project manager who is also the sole responsible person for the project, 
temporarily for the duration of the project. These personnel return to their departments after completion of the project.

To produce a commodity or a service, when two or more companies cooperate for a long period of time, a network type of organization is created.

Companies that have the systematic marketing concepts and also complement or understand each other within the construction sector may use a mixed organizational structure (such as matrix plus network) in today's economic conditions. This organizational structure should be thought to provide positive contribution to marketing mix (product, price, advertising and distribution) by outsourcing and effective use of core components.

Contrarily, having simple and functional/ hierarchical organizational structures for construction companies is a factor that may affect their marketing strategies negatively.

The key interest areas of surveyed companies are found as follows: residential construction: 16 (32.7\%); infrastructure: 12 (24.5\%); commercial construction: 9 (18.3\%); and others: $12(24.5 \%)$ out of forty nine (100\%) companies. These represent the firms' main field of activities although during the interview, the companies stated that their interest areas include other construction types as well. In the following analyses, only the three types of activity areas, namely, residential, infrastructure, and commercial constructions are considered.

The survival of construction firms that specializes in housing and has limited capital depends on the newly acquired projects. In Turkey, the increase in national income per capita and $1.3 \%$ annual population growth create a need for around 300,000 houses per year (UniCredit 2011). In addition to a number of houses the rising demand for quality houses have changed the perspective of construction companies about marketing.

There are many risks in connection with engineering, construction, financing, and operating the investment projects for companies engaged in the infrastructure works. Despite the risks, the country's medium-term economic growth spurs a demand in this area. Especially the high engineering costs, the lengthy construction time, and overtime in schedules due to technical complexities in energy and infrastructure investment projects are making up the most of these potential risks. To minimize the impact of these risks and to meet the future demand, the industry should put up their own marketing plan and policies.

The construction companies specialized in office and commercial buildings are facing a steady demand in the medium term due to strong economic growth in the country. The number of shopping centers built in the last few years in the retail sector is already indicating this demand. It is expected from these firms to have stable marketing plans and policies because of their business in these conditions.

\subsection{Companies' marketing perspectives}

The marketing perceptions of construction companies are grouped into seven categories: I: Customer satisfaction; II: Provide profit; III: Developing strategies to ensure for selling the product; IV: Customer-oriented product or service creation and pricing; V: Getting a hold in the market; VI: Providing a competitive advantage; VII: Increasing market share; VIII: Advertising the company; IX: Providing an easiness for the coming of new products or tenders. 
The answers about construction companies' marketing perspectives are shown in Figure 1. The choices are arranged from the most agreed to the least agreed in the figure based on the calculated average values. The length of whiskers represents one standard deviation from the average. According to the figure, the answers are scattered mostly on choices IV and II.

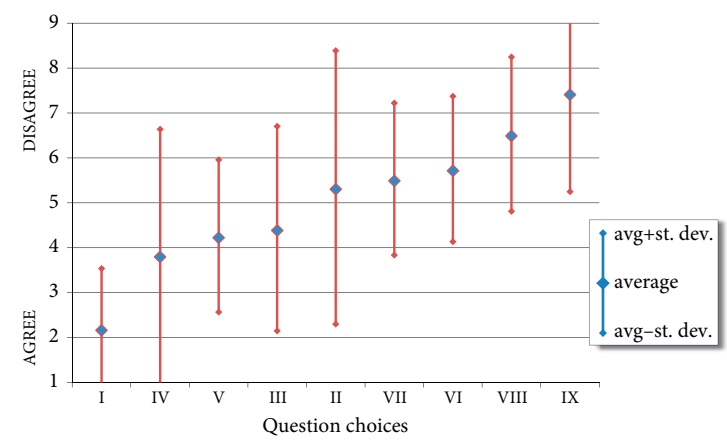

Fig. 1. Marketing perspectives of construction companies

In light of this assessment, the preferences of business managers can be ranked as I $>$ IV $>$ $\mathrm{V}>$ III $>$ II $>$ VII $>$ VI $>$ VIII $>$ IX. According to this, managers perceive marketing mainly as delivering customer satisfaction (choice I). After that, creating and pricing product or service oriented for customers are the perceived concepts in marketing (choice IV). The results suggest that managers do not see the marketing as providing easiness for the coming of new products or tenders (choice IX).

Figure 2 shows the marketing perspectives of companies according to their key interest areas. According to the figure, there are no big differences between the residential, commercial, or infrastructure firms except in two questions. The answers to two choices, namely, IV (customer-oriented product or service creation and pricing) and II (provide profit) differ. The residential construction companies perceive the marketing as providing profit more than the infrastructure and commercial companies do (choice II). On the other hand, residential companies do not see creating and pricing product or service oriented for customers as marketing to the extent that commercial companies do (choice IV). The differences may be attributed to the necessity of providing long-lasting infrastructure and commercial structures due to the increased customer awareness about quality and worthiness in addition to the high level of competition among the firms.

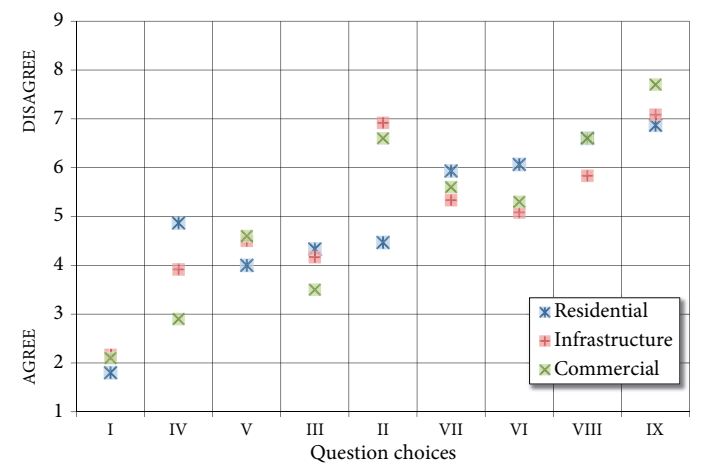

Fig. 2. Marketing perspectives of companies based on key interest areas 
Figure 3 shows the marketing perspectives of companies according to their organizational structures. Again, the two choices can be focused on to explain their divergence. Providing profit (choice II) as marketing is seen mostly by project type of organizations. Creating and pricing product or service oriented for customers (choice IV) as marketing is agreed on mostly by network type of organizations.

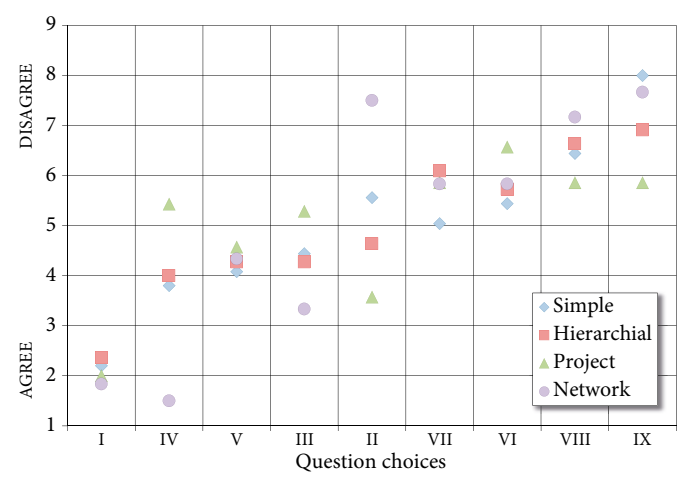

Fig. 3. Marketing perspectives of companies according to their organizational structures

\subsection{Functions of the marketing department}

Some other related data about the firms are as followed: thirteen out of forty companies have a separate marketing department. The number of personnel working in the marketing department ranges from 0 to 12 (12 people; 10 people; 3 people in 5 firms; 2 people in 2 firms; 1 person in 3 firms; and 0 person in 1 firm). Also, in four of these companies with marketing departments, one person in four firms works at other departments of the company as well. The professions of these people are as follows: $32 \%$ engineers; $11 \%$ architect; $47 \%$ business managers; and $11 \%$ other.

The organizational structure of the marketing department of a company can vary according to the company. The observations made during the survey showed that companies with a simple and functional/hierarchical organizational structure consist of one or two marketing employees, and organizations with project and network have dozens of marketing employees on staff. On the whole, putting an organizational structure helps all employees of the company to understand what the role of each person is in the marketing department.

Construction companies are asked about what the main functions or activities of marketing department should primarily be. The opinions are grouped as follows: I: Developing policies which will improve the public image of the company; II: Bringing out the advertisement process of company; III: Creating a new customer profile; IV: Preparing for bidding; $\mathrm{V}$ : Investigating the conditions of competition; VI: Determining the needs of customers; VII: Supporting to increase or sustain the profitability of the company.

Considering the distribution of values in Figure 4, preferences of business managers can be arranged as I > V > VI > III > VII $>$ IV $>$ II from the most to the least agreed on. In other words, company managers see that improving policies to increase the company's public image as the most important function of a marketing department (choice I). Other important 


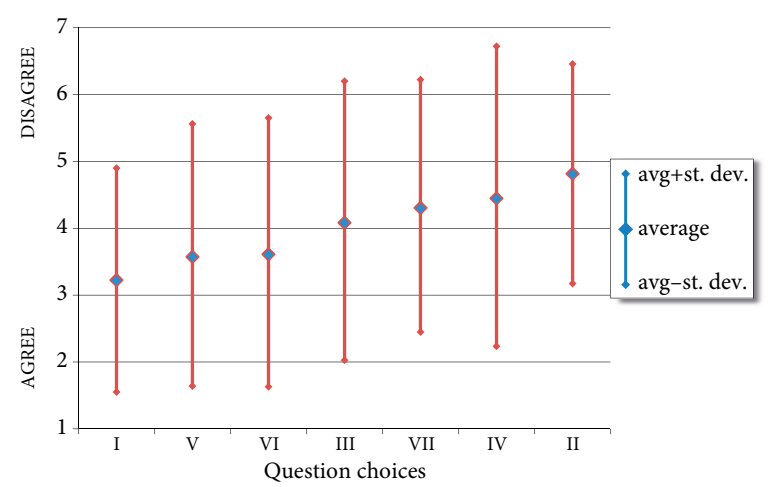

Fig. 4. Opinions about the functions of marketing department

functions as judged by the respondents are investigation of the conditions of competition (choice V) and activities for determining customer requests (choice VI). Managers expresses that preparation of a tender (choice IV) and bringing out the advertisement process of company (choice II) are the least important activities of a marketing department.

Figure 5 shows the perceived functions of marketing department according to key interest area of companies. From the figure, it can be seen that mostly the perceptions of commercial companies differ from the other types of companies in many choices. For example, investigating the conditions of competition (choice V) as a function of marketing seems to be more important for commercial construction companies. Conversely, improving policies to increase the company's public image (choice I) as a marketing function is seen to be less important for commercial construction companies. The varying perspectives of these construction firms with different main activity areas may be attributed to confusion about differing long-term economic growth forecasts within and among those sectors.

Figure 6 shows the perceived functions of marketing department according to the organizational structures of companies. Again, the companies with project and network type of organization are not agreed on many choices. For example, on choices I, V, VI, and III the project and network type of organizations have almost opposite views.

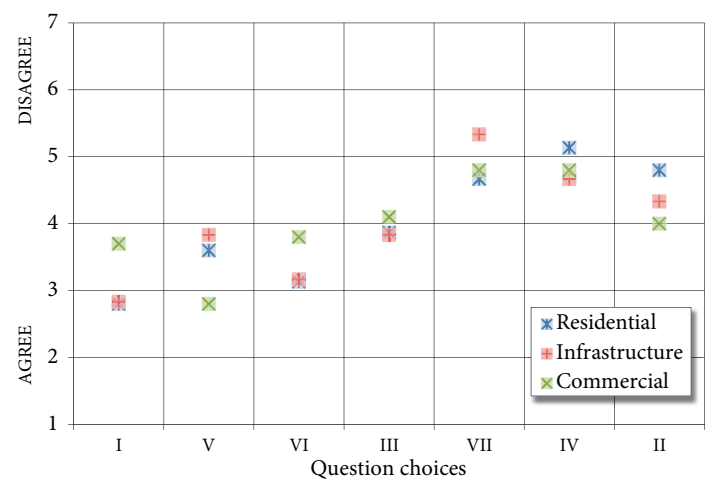

Fig. 5. The functions of marketing department based on main activity area 


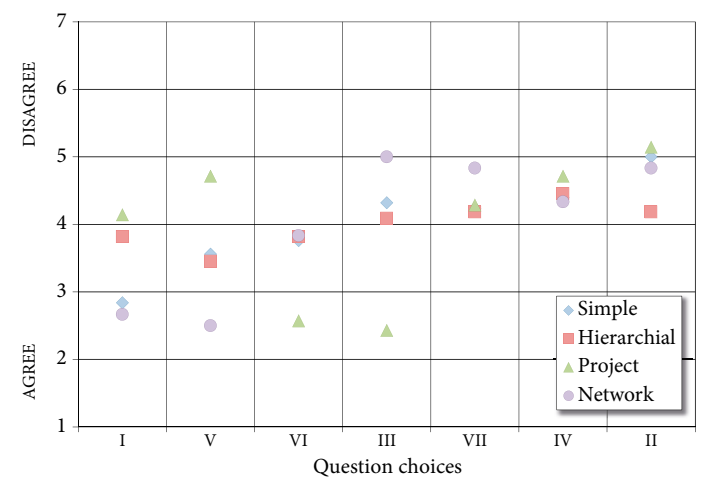

Fig. 6. The perceived function of marketing department according to organizational structure

\subsection{Internal and external business factors which affect marketing process}

Managers are asked about the business practices occur in and outside of their decision circle as listed in Table 1 and Table 2, respectively. The percentage values of responses are given in the tables. The effects of the internal and external factors of business environment are assessed by Likert scale.

Table 1. Numbers of Responses and $p$-values from One-Way ANOVA Analysis about the Internal Business Factors That Affect the Marketing Activities

\begin{tabular}{|c|c|c|c|c|c|c|c|c|c|c|c|c|c|c|}
\hline \multirow{2}{*}{ Internal business factors } & \multicolumn{5}{|c|}{$\begin{array}{l}\text { Numbers of } \\
\text { responses }\end{array}$} & \multirow{2}{*}{$\begin{array}{l}\text { Avg. } \\
\left(\mathbf{X}_{\mathrm{ao}}\right)\end{array}$} & \multirow{2}{*}{$\begin{array}{l}\text { Std. Dvt. } \\
\quad(\mathbf{s})\end{array}$} & \multicolumn{7}{|c|}{$p$-values from One-Way ANOVA analysis } \\
\hline & 1 & 2 & 3 & 4 & 5 & & & I & IV & III & VII & $\mathrm{V}$ & II & VI \\
\hline $\begin{array}{l}\text { The marketing } \\
\text { process is a waste of } \\
\text { time and money since } \\
\text { it requires detailed } \\
\text { and careful planning }\end{array}$ & 44 & 23 & 21 & 6 & 6 & 2.08 & 1.22 & - & $1 \cdot 10^{-7}$ & $4 \cdot 10^{-8}$ & $4 \cdot 10^{-8}$ & $1 \cdot 10^{-11}$ & $7 \cdot 10^{-11}$ & $1 \cdot 10^{-12}$ \\
\hline $\begin{array}{l}\text { IV The scale of the } \\
\text { marketing objectives } \\
\text { determined by the } \\
\text { own company }\end{array}$ & 8 & 10 & 35 & 14 & 33 & 3.53 & 1.28 & - & - & 0.87 & 0.75 & 0.12 & 0.10 & 0.06 \\
\hline $\begin{array}{l}\text { III Viewpoint of the own } \\
\text { business to marketing }\end{array}$ & 8 & 8 & 33 & 20 & 31 & 3.57 & 1.24 & - & - & - & 0.87 & 0.15 & 0.13 & 0.08 \\
\hline $\begin{array}{l}\text { VII Inability of upper } \\
\text { management to detect } \\
\text { the advances in the } \\
\text { business environment }\end{array}$ & 6 & 16 & 24 & 16 & 37 & 3.61 & 1.30 & - & - & - & - & 0.22 & 0.19 & 0.13 \\
\hline $\begin{array}{l}\mathrm{V} \text { Adequacy of the } \\
\text { number of employees }\end{array}$ & 0 & 16 & 20 & 18 & 45 & 3.92 & 1.15 & - & - & - & - & - & 0.87 & 0.79 \\
\hline $\begin{array}{l}\text { II The financial power } \\
\text { of the own business }\end{array}$ & 6 & 12 & 10 & 22 & 49 & 3.96 & 1.29 & - & - & - & - & - & - & 0.93 \\
\hline VI Information network & 2 & 8 & 20 & 29 & 41 & 3.98 & 1.07 & - & - & - & - & - & - & - \\
\hline
\end{tabular}

Note: Likert Scale; 1 - not at all important, 5 - very important. 
According to Table 1, the following about the internal factors that affect marketing processes can be said: Managers mention that insufficiency of information networks $\left(\mathbf{X}_{\mathbf{a o}}=3.98\right)$, the financial power of the own business $\left(\mathbf{X}_{\mathrm{ao}}=3.96\right)$, and adequacy of the number of employees $\left(\mathbf{X}_{\mathbf{a o}}=3.92\right)$ as the most important internal business factors affecting marketing activities.

An ANOVA analysis was performed between each pair of choices for the internal factors. The results are given in Table 1. According to the results in Table 1, choice I is clearly different from other choices. Additionally, the rest of the choices can be grouped into two different groups based on the $p$-values from the ANOVA analysis as follows: the first group includes IV, III, and VII; and the second group consists of V, II, and VI.

According to the analysis, managers do not consider the marketing process as the waste of time and money although the marketing activities which are done properly require extensive time and financial undertaking $\left(\mathbf{X}_{\mathrm{ao}}=2.08\right)$. In the interviews, managers said that the marketing processes involve a comprehensive data collection and analysis activities, therefore qualified manpower and financial abilities are needed.

Figure 7 shows the significance of internal business factors in marketing activities attributed by managers according to the main field of activities of companies. According to the figure, managers from the infrastructure companies responded higher significance values in all factors opposite to the opinions of managers from the residential companies.

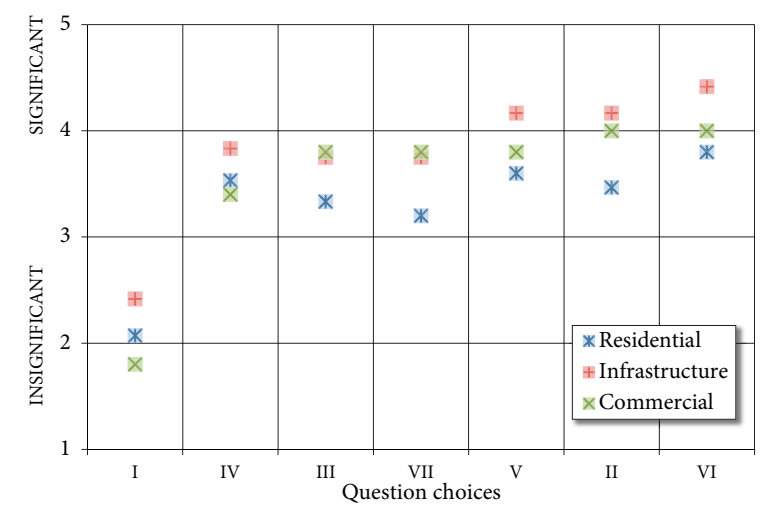

Fig. 7. Significance of internal business factors based on main activity areas

Figure 8 shows the significance of internal business factors related to organizational structure. It stands out that the network type of organizations place more significance values on internal business factors than other types of organizations do.

The responses of managers about the effects of external business factors on marketing processes are summarized in Table 2. According to the statistical values in Table 2, the following can be said:

1) Managers see the most important external business factors are (i) influencing economy and bureaucracy by political power; ever-changing government policies $\left(\mathbf{X}_{\mathrm{ao}}=3.61\right)$; (ii) constant and rapid change of the industry's marketing environment $\left(\mathbf{X}_{\mathrm{ao}}=3.22\right)$; (iii) decreased purchasing power of people as a result of deterioration in income distribution $\left(\mathbf{X}_{\mathbf{a o}}=3.12\right)$; and (iv) administrative differences and practices of companies and of professional groups located in the sector $\left(\mathbf{X}_{\mathrm{ao}}=3.06\right)$. 


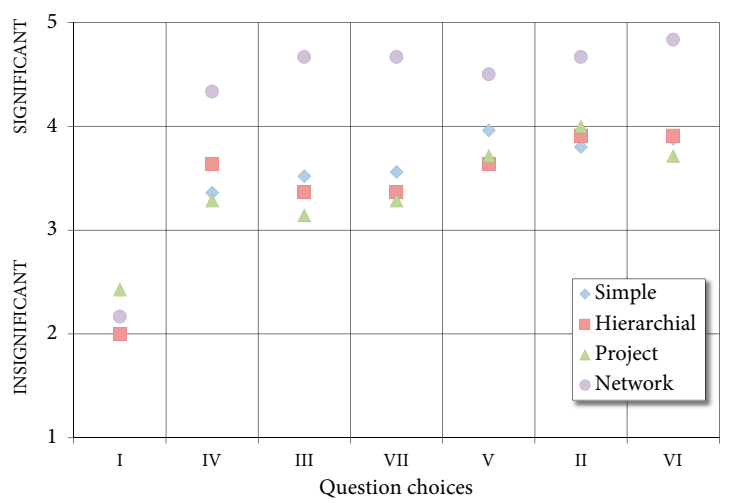

Fig. 8. Significance of internal business factors according to organizational structure

Table 2. Numbers of Responses and p-values from One-Way ANOVA Analysis about the External Business Factors That Affect the Marketing Activities

\begin{tabular}{|c|c|c|c|c|c|c|c|c|c|c|c|c|c|}
\hline & \multirow{2}{*}{ External business factors } & \multicolumn{5}{|c|}{$\begin{array}{l}\text { Numbers of } \\
\text { responses }\end{array}$} & \multirow{2}{*}{$\begin{array}{l}\text { Avg. } \\
\left(\mathbf{X}_{\mathrm{ao}}\right)\end{array}$} & \multirow{2}{*}{$\begin{array}{l}\text { Std. Dvt. } \\
\quad(\mathbf{s})\end{array}$} & \multicolumn{5}{|c|}{$\begin{array}{c}\text { p-values from One-Way ANOVA } \\
\text { analysis }\end{array}$} \\
\hline & & 1 & 2 & 3 & 4 & 5 & & & I & $\mathrm{V}$ & II & III & IV \\
\hline I & $\begin{array}{l}\text { Cultural differences of compa- } \\
\text { nies and of professional groups } \\
\text { located in the sector }\end{array}$ & 59 & 12 & 12 & 8 & 8 & 1.94 & 1.34 & - & $6 \cdot 10^{-5}$ & $3 \cdot 10^{-5}$ & $4 \cdot 10^{-6}$ & $7 \cdot 10^{-9}$ \\
\hline $\mathrm{V}$ & $\begin{array}{l}\text { Administrative differences and } \\
\text { practices of companies and of } \\
\text { professional groups located in } \\
\text { the sector }\end{array}$ & 12 & 24 & 29 & 14 & 20 & 3.06 & 1.31 & - & - & 0.82 & 0.53 & 0.04 \\
\hline II & $\begin{array}{l}\text { Decreased purchasing power of } \\
\text { people as a result of deteriora- } \\
\text { tion in income distribution }\end{array}$ & 10 & 29 & 24 & 12 & 24 & 3.12 & 1.35 & - & - & - & 0.70 & 0.07 \\
\hline III & $\begin{array}{l}\text { Constant and rapid change of } \\
\text { the industry's marketing envi- } \\
\text { ronment }\end{array}$ & 10 & 18 & 29 & 24 & 18 & 3.22 & 1.25 & - & - & - & - & 0.13 \\
\hline IV & $\begin{array}{l}\text { Influencing economy and } \\
\text { bureaucracy by political power; } \\
\text { ever-changing government } \\
\text { policies }\end{array}$ & 6 & 14 & 24 & 22 & 33 & 3.61 & 1.26 & - & - & - & - & - \\
\hline
\end{tabular}

Note: Likert Scale; 1 - not at all important, 5 - very important.

2) Cultural differences of companies and of professional groups located in the sector is not seen as an important external business factor on average $\left(\mathbf{X}_{\mathbf{a o}}=1.94\right)$.

The external business factors affecting the marketing activities are statistically analyzed. For each pair of factors a one-way ANOVA analysis is performed and resulted $p$-values are presented in Table 2 . According to the $p$-values, clearly choice I is different from other choices. Whereas, other choices can be said to form two groups such as, group one consists of choices V, II, and III and group two including only choice IV.

Figure 9 shows the external business factors as seen to be important in marketing processes related to the key interest areas of companies. From the figure, it can be said that the companies whose main field of activity is infrastructure put more importance on external 
business factors. If the internal and external business factors are evaluated together, it can be said that all companies see the internal business factors more important than the external business factors since the averages in internal business factors concentrates around the value of four compared to the averages in external business factors which concentrates less than the value of four.

Figure 10 shows the external business factors effective in marketing processes according to the organization types of companies. Similar to Figure 8, the network type of organizations place more importance on all external business factors.

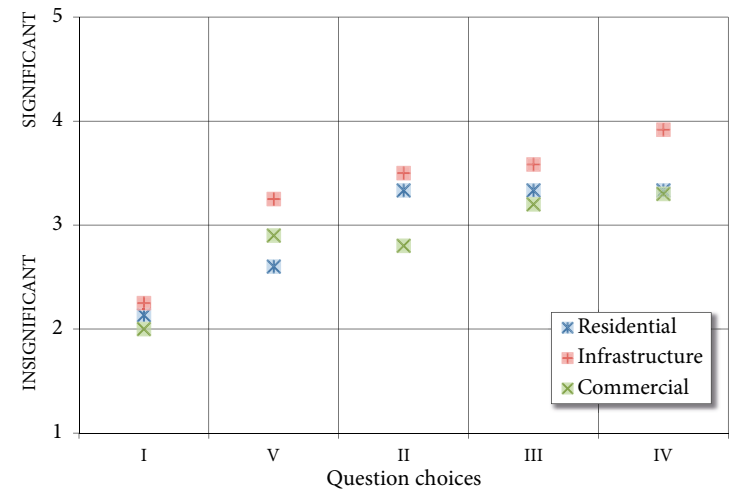

Fig. 9. Significance of external business factors based on main activity areas

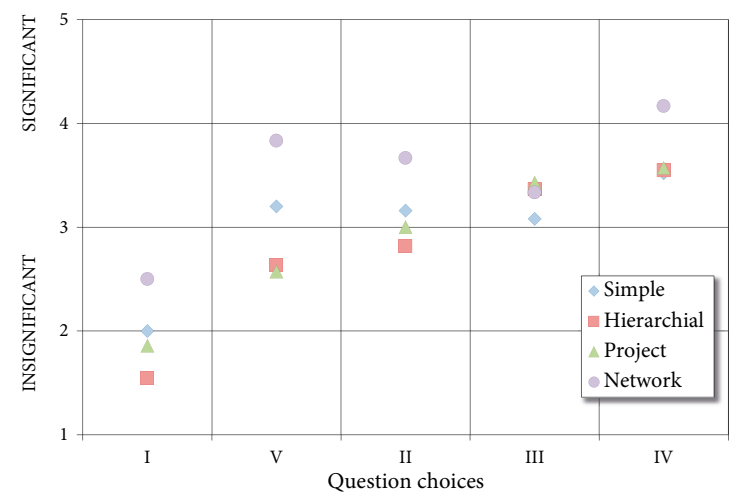

Fig. 10. Significance of external business factors according to organizational structure

\subsection{How the marketing activities are performed}

In the survey, the managers are also asked about the marketing activities done in their companies. The responses are summarized in Table 3.

The results in Table 3 show that these companies have plans for marketing even though the companies' organizational structures may not be suitable. Along with this, the respondents mention that they adopt mainly the policies regarding to establish a market share. These findings reveal that these construction companies do not have an integral and systematic approach for marketing strategies. 
Table 3. Questionnaire about the Marketing Activities Conducted Within a Company

\begin{tabular}{clc}
\hline & \multicolumn{1}{c}{ Question } & \% of “yes" answers \\
\hline IV & Do you collect information about the market? & 90 \\
III & Do you determine the needs and desires of the customers? & 84 \\
XII & Do you make queries about the whole job? & 78 \\
I & Do you have organizational policies regarding marketing? & 76 \\
II & Do you have strategic policies regarding marketing? & 73 \\
V & Do you study the market opportunities? & 73 \\
VII & Do you analyze data about the market? & 73 \\
VI & Do you make efforts concerning productivity? & 71 \\
X & $\begin{array}{l}\text { Do you exploit the marketing activities, such as, design, procurement, } \\
\text { and advertising, in your company? }\end{array}$ & 69 \\
XIII & Do you include feedback activities in your marketing works? & 61 \\
XI & Do you evaluate the productivity performances? & 55 \\
IX & Do you have a written marketing plans or policies? & 51 \\
VIII & $\begin{array}{l}\text { Do you do market-oriented technical and scientific assessments } \\
\text { (such as, SWOT Analysis)? }\end{array}$ \\
\hline
\end{tabular}

Managers who said that they do not have written marketing plans give existence of rapidly changing environment, taking time and money to prepare such a plan and hence seeing the plan preparation as a wasteful activity, and considering a written plan as not practical as results. Nonetheless, they also say that there is an unofficial marketing plan which usually has been prepared by shareholders or managers. It is said that the progresses regarding this unofficial plan is monitored by keeping specific and weekly reports through the regular meetings. The reasons for not having any strategy to develop a written marketing plan can be the presently existing customers and the confidence in their current approach.

The managers stated that they were inquiring about the whole job by evaluating the output performances and providing feedback activities. They, however, did not specify the extent of these feedback activities.

Figures 11 and 12 show the marketing activities fulfilled in the companies separated in to their key interest areas and separated in to their organization structures, respectively. The biggest discrepancies are seen in choices VIII (do you do market-oriented technical and scientific assessments?) and V (do you study the market opportunities?) in Figure 11. In both questions, commercial construction companies have given more positive responses than the residential construction companies have done. In general, residential companies responded less positively to questions, which may mean that they spend fewer efforts about marketing activities. Also, according to Figure 12, network type of organizations gave more positive answers to questions compared to hierarchical type of organizations. 


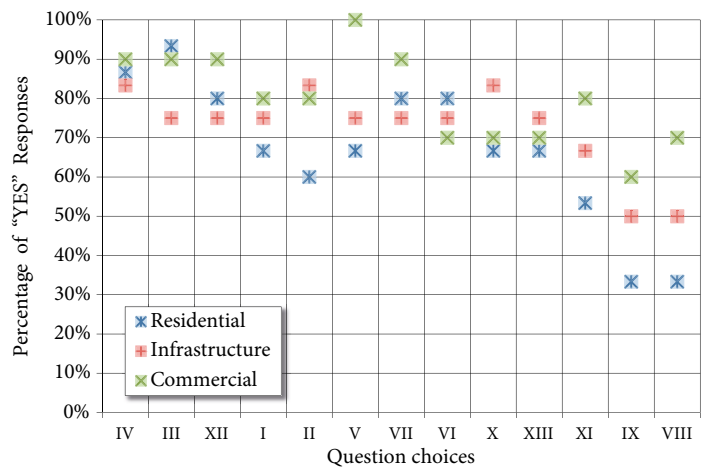

Fig. 11. Marketing activities done in the company according to key interest fields

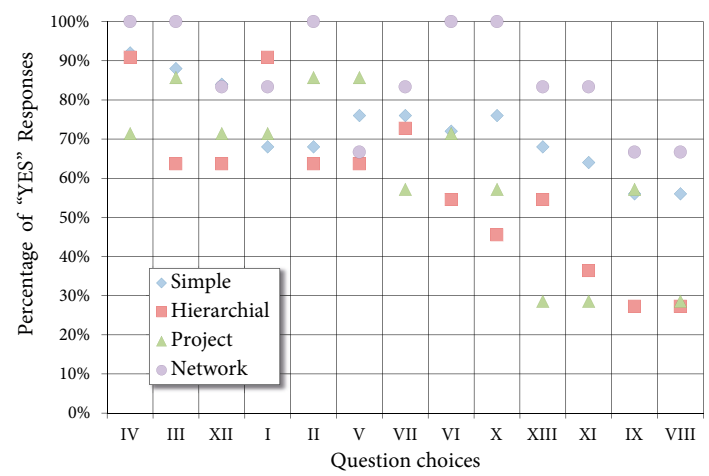

Fig. 12. Marketing activities done in the company according to organizational structure

Since the commercial construction sector is affected by the economy growth/decline rate more than the residential construction sector does, the commercial construction firms undertake technical and scientific assessments (such as, SWOT analysis) to evaluate market opportunities. Meanwhile, due to high demand in residential construction sector, according to the Figure 11, the firms in this sector do not seem to be implementing many marketing activities, such as design, procurement, advertisement, and etc.

\subsection{What kind of efforts are spent in promotion process}

In the survey, the managers are asked about the promotion activities done in their companies. The responses are summarized in Table 4.

According to Table 4, an appropriate advertisement and presentation is seen to be required in promotion process in marketing activities.

Figure 13 shows the efforts spent in promotion activities related to the main field of activity of companies. According to the figure, commercial construction companies place more emphasis on promotion activities while the residential construction companies put the least emphasis on related activities. 
Table 4. Questionnaire results about the Efforts Spent in Promotion Process

\begin{tabular}{clc}
\hline \multicolumn{1}{c}{ Question } & \% of “yes" answers \\
\hline I & Is there a need for advertisement and presentation? & 67 \\
IV & $\begin{array}{l}\text { Is the prepared advertisement or presentation appeal to customer's } \\
\text { needs and desires? }\end{array}$ & 67 \\
V & $\begin{array}{l}\text { Is the marketing process requires different activities (cocktail party, } \\
\text { brochure, catalog, etc.) }\end{array}$ \\
II & Is the main theme of the advertisement determined? & 51 \\
III & Is the main theme of the presentation determined? & 53 \\
\hline
\end{tabular}

Figure 14 shows the percentage of positive answers to questions about the promotion activities related to the organizations structures of companies. The biggest discrepancy is seen on question $\mathrm{V}$ (does the marketing process require different activities?).

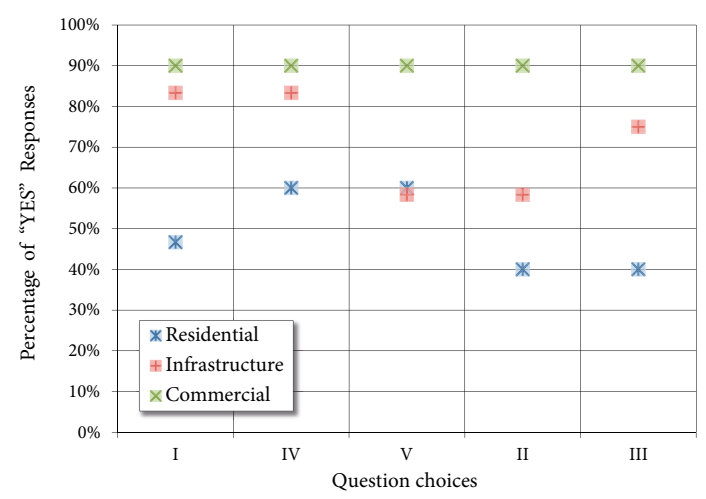

Fig. 13. Efforts spent in promotion activities according to key interest fields

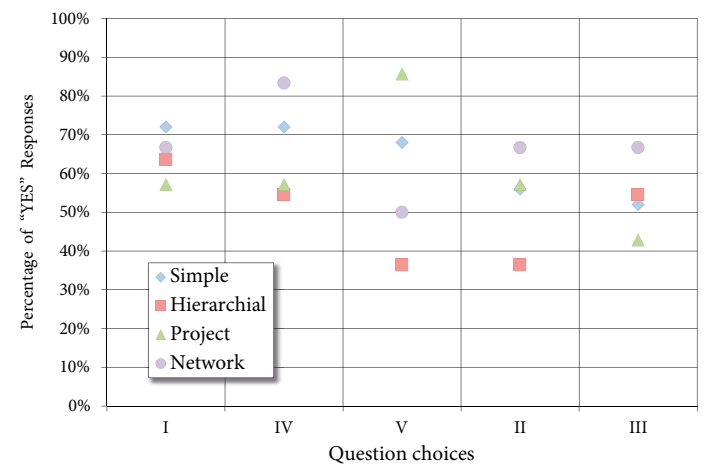

Fig. 14. Spent efforts related to promotion based on organizational structure

\section{Conclusions}

The continuous increase in competition, changes of customer demands, and opening up new markets force companies to pay more attention to marketing and advertising efforts. The companies also need to devote more time for systematic and planned marketing approaches to 
reach their specific company objectives along with the developed strategies. Nowadays, time, cost, and quality requirements become compelling elements of market pressure especially at big and medium sized companies. These issues turn the companies' focus on self-development of these matters and search various innovations in internal organizational and functional configurations of their own companies. Today, having the marketing department in the organizational structure of particularly large companies has become a necessity for competition.

The overall result deduced from this study is that the construction companies do not have a systematic approach to marketing. The companies have adopted primarily the approaches to keep their current places in the sector and to marketing with the experiences and the knowledge about existing practices. The survey results indicate that construction companies do not take on seriously the systematic marketing because of these factors; (a) situated in an environment that has constant and rapid changes; (b) requiring the marketing process more time and financial commitments; (c) having clients already; and (d) believing that their current approaches are good and adequate. The perception and application of the marketing are discussed based on the organizational structure and key interest areas of construction companies. The opinions about the different aspects of marketing vary on the construction companies depending on their actively involved fields and their organizational structures. Starting from this point on, in future studies, a model which helps to implement a systematic marketing approach for the construction companies will be prepared.

\section{Acknowledgements}

The authors would like to thank the Mustafa Kemal University Scientific Research Directorate (Project number: 05-D-0202) for providing financial support for this study.

\section{References}

Arditi, D.; Polat, G.; Makinde, S. A. 2008. Marketing practices of U.S. contractors, Journal of Management in Engineering 24(4): 255-264. http://dx.doi.org/10.1061/(ASCE)0742-597X(2008)24:4(255)

Banaitis, A.; Banaitiene, N. 2005. Research into advertising in construction: analysis of Lithuanian and Swedish experience, Technological and Economic Development of Economy 11(4): 248-259.

Bentley, J. I. W. 1987. Construction tendering and estimating. London: E and F. N. Spon, 113-115.

Cicmil, S.; Nicholson, A. 1998. The role of the marketing function in operations of a construction enterprise: misconceptions and paradigms, Management Decision 36(2): 96-101. http://dx.doi.org/10.1108/00251749810204179

Costa, A. A.; Tavares, L. V. 2013. Advanced multicriteria models to promote quality and reputation in public construction e-marketplaces, Automation in Construction 30: 205-215. http://dx.doi.org/10.1016/j.autcon.2012.11.029

Cova, B.; Salle, R. 2005. Six key points to merge project marketing into project management, International Journal of Project Management 23: 354-359. http://dx.doi.org/10.1016/j.ijproman.2005.01.006

Crespin-Mazet, F.; Ghamri, P. 2007. Co-development as a marketing strategy in the construction industry, Industrial Marketing Management 36: 158-172. http://dx.doi.org/10.1016/j.indmarman.2006.02.011

Crespin-Mazet, F.; Portier, P. 2010. The reluctance of construction purchasers towards project partnering, Journal of Purchasing and Supply Management 16: 230-238.

http://dx.doi.org/10.1016/j.pursup.2010.06.001 
Daft, R. L. 1998. Organization theory and design. Ohio, USA: South-Western College Publishing.

Demirci, M.; Oral, E.; Erdis, E. 2003. Insaat firmalarında cagdas pazarlama ve teklif fiyatı belirleme stratejileri, Çukurova Üniversitesi Mühendislik Mimarlkk Fakültesi Dergisi 18(1): 49-64. (in Turkish).

Dikmen, I.; Birgonul, M. T.; Ozcenk, I. 2005. Marketing orientation in construction firms: Evidence from Turkish contractors, Building and Environment 40: 257-265. http://dx.doi.org/10.1016/j.buildenv.2004.07.009

Erdis, E.; Demirci, M.; Kılıc, A.; Ornek, M. 2008. Türk insaat firmalarının sistematik pazarlama anlayısını etkileyen faktorler, Çukurova Üniversitesi Mühendislik Mimarlk Fakültesi Dergisi 23(1): 306-320. (in Turkish).

Hakansson, H.; Johanson, J.; Wootz, B. 1976. Influence tactics in buyer-seller processes, Industrial Marketing Management 5: 319-332. http://dx.doi.org/10.1016/0019-8501(76)90014-6

Hardy, L. W.; Davies, E. 1983. The marketing of services in the UK construction industry, European Journal of Marketing 17(4): 5-17. http://dx.doi.org/10.1108/EUM0000000004813

Huff, D. J. 1984. Professional marketing in small civil engineering firms, Journal of Professional Issues in Engineering 110(3): 127-141. http://dx.doi.org/10.1061/(ASCE)1052-3928(1984)110:3(127)

Jaradat, S.; Whyte, J.; Luck, R. 2013. Professionalism in digitally mediated project work, Building Research and Information 41(1): 51-59. http://dx.doi.org/10.1080/09613218.2013.743398

Kajander, J. K.; Sivunen, M.; Vimpari, J.; Pulkka, L.; Junnila, S. 2012. Market value of sustainability business innovations in the construction sector, Building Research and Information 40(6): 665-678. http://dx.doi.org/10.1080/09613218.2012.703893

Korkmaz, S.; Messner, J. I. 2008. Competitive positioning and continuity of construction firms in international markets, Journal of Management in Engineering 24: 207-216.

http://dx.doi.org/10.1061/(ASCE)0742-597X(2008)24:4(207)

Mochtar, K.; Arditi, D. 2001. Role of marketing intelligence in making pricing policy in construction, Journal of Management in Engineering 17: 140-148. http://dx.doi.org/10.1061/(ASCE)0742-597X(2001)17:3(140)

Perreault, Jr.; Cannon, J.; McCarthy, E. J. 2010. Basic marketing. NewYork, USA: McGraw-Hill Publishing. Pettinger, R. 1998. Construction marketing: strategies for success. London: Macmillan Press.

Pheng, L. S.; Ming, K. H. 1997. Formulating a strategic marketing mix for quantity surveyors, Marketing Intelligence and Planning 15(6): 273-280. http://dx.doi.org/10.1108/02634509710184857

Polat, G.; Donmez, U. 2010a. ANP-based marketing activity selection model for construction companies, Construction Innovation 10(1): 89-111. http://dx.doi.org/10.1108/14714171011017590

Polat, G.; Donmez, U. 2010b. Marketing management functions of construction companies: evidence from Turkish contractors, Journal of Civil Engineering and Management 16(2): 267-277. http://dx.doi.org/10.3846/jcem.2010.31

Skaates, M. A.; Tikkanen, H.; Alajoutsijarvi, K. 2002. Social and cultural capital in project marketing service firms: Danish architectural firms on German market, Scandinavian Journal of Management 18(4): 589-609. http://dx.doi.org/10.1016/S0956-5221(01)00028-8

Smyth, H. 2000. Marketing and selling construction services. London: Blackwell Science.

Stuart, S.; Slatter, P. 1991. Strategic marketing variables under conditions of competitive bidding. London Business School, London, U.K.

Tang, Y.; Wang, P.; Zhang, Y. 2007. Marketing and business performance of construction SMEs in China, Journal of Business and Industrial Marketing 22(2): 118-125. http://dx.doi.org/10.1108/08858620710730230

UniCredit. 2011. Real estate country facts [online], [cited 18 February 2012]. Available from Internet: http://www.immobilienrating.at/documents/E_RealEstate_Tuerkei_29062011_16h.pdf 
Uslay, C.; Malhotra, N. K.; Allvine, F. C. 2006. Predatory pricing and marketing theory: applications in business-to-business context and beyond, Journal of Business-to-Business Marketing 13(3): 65-116. http://dx.doi.org/10.1300/J033v13n03_03

Yisa, S. B.; Ndekugri, I.; Ambrose, B. 1995. The marketing function in the UK construction contracting and professional firms, Journal of Management in Engineering 11(4): 27-33. http://dx.doi.org/10.1061/(ASCE)0742-597X(1995)11:4(27)

Yisa, S. B.; Ndekugri, I.; Ambrose, B. 1996. A review of changes in the UK construction industry: their implications for the marketing of construction services, European Journal of Marketing 30(3): 47-64. http://dx.doi.org/10.1108/03090569610107427

Zavadskas, E. K.; Kaklauskas, A.; Banaitis, A. 2004. Development strategy of construction sector in Lithuania until 2015. part 2: Vision, mission, strategic goals and actions of implementation of strategic objectives, Technological and Economic Development of Economy 10(1): 7-21.

Ercan ERDIS is an Associate Professor of Civil Engineering in the Faculty of Engineering at Mustafa Kemal University. Dr Erdis is a member of Chamber of Civil Engineers of Turkey. Dr Erdis is actively involved in construction management areas. Dr Erdis received his MS and PhD degrees in Civil Engineering at the Mustafa Kemal University in 2001 and Cukurova University in 2004, respectively.

Hilmi COSKUN is an Assistant Professor of Civil Engineering in the Faculty of Engineering at Mustafa Kemal University. Dr Coskun is a member of Chamber of Civil Engineers of Turkey. Dr Coskun is actively involved in construction management and engineering education research areas. Dr Coskun received his MS and PhD degrees in Civil Engineering at the Old Dominion University in 1998 and North Carolina State University in 2002, respectively.

Mustafa DEMIRCI is an Assistant Professor of Civil Engineering in the Faculty of Engineering at Mustafa Kemal University. Dr Demirci is a member of Chamber of Civil Engineers of Turkey. Dr Demirci is actively involved in hydrolic, construction management areas. Dr Demirci received his MS and PhD degrees in Civil Engineering at the Mustafa Kemal University in 2001 and Cukurova University in 2006, respectively. 